\title{
The Impact of Stone Mining on Community Health Around Mining in North Moramo District
}

\author{
Mohamad Guntur Nangi ${ }^{1, *}$, Titi Saparina ${ }^{1}$, Sari Arie Lestari ${ }^{2}, \operatorname{Juslan}^{1}$
}

\author{
${ }^{1}$ Public Health Study Program, STIKES Mandala Waluya, Kendari, Indonesia \\ ${ }^{2}$ Nursing Study Program, STIKES Mandala Waluya, Kendari, Indonesia \\ *Corresponding author.Email: mohamad.guntur@gmail.com
}

\begin{abstract}
Mining activities on a large scale without ignoring the environment and surrounding communities can result in a variety of negative impacts that are felt in the short and long term, including health problems. This study aims to analyze the impact of quarry stone mining on the health of communities around mining in Kec. North Moramo Konawe Selatan District in 2019.This research uses the analytic survey method, with a cross-sectional study. The population in this study is the Head of the Family (KK) Rarowatu Village who lives and lives around the quarry stone quarry area with a radius of 500 meters from the mine with a sample of 39 people. Data analysis was performed using the Chi-Square test with a $5 \%$ confidence interval.The results showed that there was a strong relationship between the distance of residence $(\mathrm{P}$-value $=0.00)$ and a weak relationship between the length of stay (P-value $=0.03$ ) with health complaints experienced by residents. The negative impact of mining activities is very strongly felt by people who live close / <200 M from the mining site. Therefore it is recommended to local governments to give mining location permits far from residential areas.
\end{abstract}

Keywords: stone mining, community health, North Moramo

\section{INTRODUCTION}

Mining activities are included in industrial activities, each industrial activity will definitely produce pollutants, pollutants can be likened to negative pressure on the surrounding environment and this environmental pressure will have an effect on humans as part of the environment. The effect of environmental stress on humans can be a decrease in physical and non-physical quality (psychology) and this effect will also trigger the emergence of various environmental conflicts that exist [1].

Stone mining also causes many health problems. The problems that have arisen quite temporarily are mainly related to flying stone dust. Stone dust contains chemicals that can cause lung disease. The disease appears in people who are at the site of a rock quarry, or in the area of rock transportation, inhaling rock dust continuously, and who are most at risk are workers [2].

Data from the International Labor Organization (ILO) concludes that, on average, 6000 people die, equivalent to one person every second, or 2.2 million per year due to illness or work accidents related to their workforce. The physical condition of the workplace environment where workers carry out their daily activities contains many dangers, directly or indirectly, for the health and safety of workers [3]. Among health problems caused by the work environment, dust is one source of interference that cannot be ignored. This often causes respiratory distress or can interfere with lung function [4].
From preliminary observations made by researchers, it was found vehicles exiting the transport of stone from the results in and out to transport the stones excavated by the miners. The type of rock excavated / natural resources used is igneous rock. This rock is also called the Mountain stone or Jetty stone. This rock is a type of igneous rock where it can be used to produce objects, other goods, and can also be used for dams.

The rock mining undertaken has negative impacts and positive impacts. Impact simply can be said as influence or effect. The negative impact is the formation of steep slopes that are very dangerous for the miners, air pollution, lots of open land, dusty and sandy soil, landslides, frenzied miners, dirty air due to processing and the roads that are traversed by the mine transporters are quickly damaged due to overload. In addition to the negative impacts there is also a positive impact from the mining of the stone, ie residents who are around the mine get income from the mining results.

Based on preliminary observations of the study, some residents who were met complained and were disturbed because dust was flying due to the activities of the mines and vehicles reaching the settlement and this took place every day from 07.00 to 16.00 WITA. Complaints that are felt a lot are respiratory disorders and other than that many other diseases suffered by residents are itching. According to one resident, they often close the doors and windows of the house to prevent dust from entering the house. As a result, the room becomes moist, making it easier for lice / bacteria to multiply. 
Based on the distribution of data from the results of this study, most (43.6\%) were 31-40 years old. Based on work, the majority $(30.8 \%)$ are self-employed. Based on the variable studied, the distance of residence, the majority of respondents $(74.4 \%)$ were living $\geq 200$ meters from the location of mining activities while the length of stay, most $(51.3 \%)$ respodents lived for $<5$ years. And based on complaints experienced by residents / family members in the past 1 month that most $(53.8 \%)$ experienced health problems such as respiratory, skin or hearing problems.

\section{RESULTS AND DISCUSSION}

Table 1. Characteristics of Respondents

\begin{tabular}{lcc}
\hline Characteristics of & $\mathbf{n}$ & \% \\
\hline Age (years) & 7 & 17,9 \\
$21-30$ & 17 & 43,6 \\
$31-40$ & 12 & 30,8 \\
$41-50$ & 3 & 7,7 \\
$>50$ & & \\
Work & 8 & 20,5 \\
Farmers & 10 & 25,6 \\
Trader & 12 & 30,8 \\
Entrepreneurs & 4 & 10,3 \\
TNI/POLRI & 5 & 12,8 \\
Civil Servant & & \\
Distance of & & \\
Residence & 10 & 25,6 \\
Near (<200 meters) & 29 & 74,4 \\
Distant ( $\geq 200$ & & \\
meters) & & \\
Length of Stay & & \\
(Years) & & \\
Old ( $\geq 5$ years) & 19 & 48,7 \\
New (<5 years) & 20 & 51,3 \\
Health Disorders / & & \\
Complaints & & 53,8 \\
Yes & & 46,20 \\
No & 21 & \\
\hline
\end{tabular}

In this study also obtained results that show that there is a strong relationship between distance of residence (Pvalue $=0.00$ ) and a weak relationship between length of stay
(Pvalue $=0.03)$ with health complaints experienced by residents who live around the stone mine area in Rarowatu village, as seen in table 2 below. 
Table 2. Bivariate Analysis of Health Disorders / Complaints.

\begin{tabular}{|c|c|c|c|c|}
\hline \multirow[t]{2}{*}{ Variable } & \multicolumn{2}{|c|}{$\begin{array}{l}\text { Disorders / Health } \\
\text { Complaints }\end{array}$} & \multirow[t]{2}{*}{$\begin{array}{c}P \\
\text { Value }\end{array}$} & \multirow[t]{2}{*}{$\varphi$} \\
\hline & Yes & No & & \\
\hline \multicolumn{5}{|l|}{$\begin{array}{l}\text { Distance of } \\
\text { Residence }\end{array}$} \\
\hline $\begin{array}{c}\text { Near }(<200 \\
\text { meters })\end{array}$ & $10(100 \%)$ & $0(0 \%)$ & 0,000 & 0,634 \\
\hline $\begin{array}{c}\text { Distant }(\geq 200 \\
\text { meters })\end{array}$ & $8(27,6 \%)$ & $21(72,4 \%)$ & & \\
\hline \multicolumn{5}{|l|}{$\begin{array}{l}\text { Length of Stay } \\
\text { (Years) }\end{array}$} \\
\hline Old $(\geq 5$ years $)$ & $12(63,2 \%)$ & $7(36,8 \%)$ & 0,038 & 0,332 \\
\hline New $(<5$ years $)$ & $6(30 \%)$ & $14(70 \%)$ & & \\
\hline
\end{tabular}

Distance is a number that shows how far an object changes its position through a certain path. In physics or in everyday terms, distance can be an estimate of the physical distance of two positions based on certain criteria. Distance of residence in this study is the distance between a residences with a quarry stone mining location. Based on the results of statistical tests, obtained Pearson Chi Square 15,690 with Pvalue 0,000 because pValue 0,000 is less than 0.05 then there is a relationship between residence distance and health complaints / complaints experienced by citizens, with phi value $=0.634$, this shows a strong relationship between the two variables. The results of this study are in line with the study of Erna Widhiyanti (2015) that there is a relationship between the distance of residence from the location of the tile industry to the decline in lung function of the population in Kedawung Village, Pejagoan District, Kebumen Regency [6]. The observations at the time of the study also showed dusty environmental conditions, both generated by the activity of breaking rocks, but also came from the fumes of truck trucks in and out and dust from roads damaged by frequent passage by heavy vehicles.

Length of stay can indicate a person's length of exposure to the risk of exposure which can cause health problems. The results of this study indicate, the length of stay shows there is a relationship of disorders / health complaints experienced by residents with a value of Phi 0.332 , this shows a weak relationship between the two variables. This can be caused because based on the results of observations at the time of the study, health problems experienced by most residents who are acute. Length of stay $\geq 5$ years many experience health problems $(63.2 \%)$ be it breathing, skin or hearing. Whether or not a person lives in an area will affect the health status of the individual. Areas that have been declared at risk of a disease, if you stay in a state for a long time will have the risk of disease.

\section{CONCLUSION}

There is a strong relationship between the distance of residence and there is a weak relationship between length of stay with health problems / complaints in the communities around the Batubatu mine in Rarowatu subdistrict, North Moramo District.

\section{REFERENCES}

[1] Hidayat S, P P, Hardiman G. Kajian Kebisingan Dan Persepsi Ketergangguan Masyarakat Akibat Penambangan Batu Andesit Di Desa Jeladri, Kecamatan Winongan, Kabupaten Pasuruan Jawa Timur. Jurnal Ilmu Lingkungan. 2012 Nov;10(2):95-9.

[2] Maryuningsih Y. Analisis dampak industri stockpile batu bara terhadap lingkungan dan tingkat kesehatan masyarakat desa pesisir rawaurip kec. Pangenan kab. Cirebon. Scientiae Educatia: Jurnal Pendidikan Sains [Internet]. 2015;5(2). Available from: http://syekhnurjati.ac.id/jurnal/index.php/sceducatia/articl e/view/490.

[3] Basalama FA. Hubungan antara intensitas kebisingan dengan nilai ambang dengar tenaga kerja di bagian produksi pt. Putra karangetang popontolen minahasa selatan. KESMAS: Jurnal Kesehatan Masyarakat Universitas Sam Ratulangi [Internet]. 2015;4(1). Available from: https://ejournal.unsrat.ac.id/index.php/kesmas/article/view $\underline{17235}$

[4] Suma'mur. Hygiene Perusahaan dan Kesehatan Kerja. CV.Sagung Seto; 2009.

[5] Sugiyono. Metode Penelitian Kuantitatif Kualitatif dan R\&D. Alfabeta; 2010.

[6] Widhiyanti E, Widowati E, Fibriana AI. Perbedaan Jarak Tempat Tinggal Dari Lokasi Industri Genteng Terhadap Penurunan Fungsi Paru Penduduk Di Desa Kedawung Kecamatan Pejagoan Kabupaten Kebumen. Unnes Journal of Public Health. 2015 Jul;4(3):40-7. 